\title{
Political and Socio-Economic Roots of Uprisings in the Arab World
}

Gaziza Kurpebayeva ${ }^{\dagger}$

\section{Abstract}

The purpose of the research is to determine the political and socio-economic roots of the Arab spring and define its consequences. The article demonstrates similar and distinct features of revolutions in the Middle East and North Africa (MENA) countries. Particular attention is paid to the transformational consequences in this region. The study results show that the Arab Spring has not brought optimistic changes but worsened socio-economic problems. The Arab Spring uprisings have led to riots, civil wars, social militarisation, the revival of terrorist organisations that affected the economy. The phenomenon of the Arab spring has appeared because of mass discontents with the ruling regimes. This phenomenon is associated with a wave of protests in MENA that have led to a transformation of political, social, inter-regional, economic and financial systems of the region. Revolutions and civil wars have forced migrations to Europe. In turn, this has destabilised the European labour market and drawn the attention of governments to the growing Islamisation of the cultural sphere. The study is interdisciplinary and assesses change of political regimes in Arabic societies.

Keywords: Arab Spring; Uprisings; Political and Social Factors; MENA; Revolution

\footnotetext{
† Emails: kurpebayeva.gaziz@rambler.ru; gaziza-k@mail.ru

(C) 2020 Kurpebayeva. This is an Open Access article distributed under the terms of the Creative Commons Attribution License (http://creativecommons.org/licenses/by/2.0), which permits unrestricted use, distribution, and reproduction in any medium, provided the original work is properly cited.
} 


\section{Introduction}

Arab spring initially has been regarded as an expression of optimism and noble intentions to shift the region's political despotism, totalitarianism and autocracy to democracy and modernity, however, its aftermath has illuminated destructive civil wars. On the one hand, extremist and radical regimes constitute acts of violence, and on the other hand, Arab states suffer from uprisings and insecurity (Vida \& Cenit, 2017). These two factors subsequently have turned the region into a zone with high volatility and a hostile environment. Consequently, the movement cannot be characterised as the Arab spring because it has not revealed any positive aspects (Shayakhmetov et al., 2018). Besides, the adverse effects of popular uprisings are due to the actions of most extreme religious movements such as "Islamic Nahda", which means "Islamic awakening" that invariably seeks to overthrow secular regimes, whether military or hereditary and restore the Empire of the Islamic Caliphate that represents the ideological hostility to Western civilisation and its values (Koehler, 2017).

The history of humankind reflects continuous changes in political, social and economic aspects of civil society. In search of peace and harmony, every society has experienced riots and outbursts against injustice and exploitation. A just society with a freedom of expression is the aim of most uprisings, which may lead to social and economic changes (Spierings, 2019). Nevertheless, uprisings have played a decisive role in the evolution of civil society. In a simplified sense, revolution is a synonym to change (Tsapko et al., 2018). However, in a broader sense, revolution is a moment in the history of class struggle that leads to radical, violent changes in the class basis of the political structure. Each revolution is characterised by a change that affects the basic written or unwritten laws (Al-Shammari \& Willoughby, 2019). Such revolutions affected the Middle East and North Africa region in December 2010.
The article consists of five sections demonstrating the conducted study. As one can see, the introduction section provides a conceptual overview of the Arab Spring phenomenon; the methodological framework describes the methodological foundations on which the research procedure is built. The results section is divided into two sections, namely "political background" and "socioeconomic background". It presents in detail the specifics of the processes that have occurred in public life during the Arab Spring. The discussion section critically evaluates the events and presents a possible perspective for the global community, while the conclusion section provides a comprehensive review of the findings generated during the study.

\section{Methodological Framework}

The study is based on a systemic analysis of complex and contradictory interaction of economic, social and political processes. An interdisciplinary approach to the analysis of political, demographic and economic processes has helped to identify the true causes of the studied events. This study is descriptive and analytical. The study focuses on available data and information to understand and explain the research problem. Secondary sources such as books, articles and essays are used. The results of this study are discussed in the following sections.

\section{Results}

\section{Political Background}

Various terms are used like Arab Spring, Arab revolution, Islamist Spring, Jasmine revolution and so on to describe the revolutions and uprisings that have begun in Tunisia, peaked in early 2011 and spread throughout the region undermining the political and socio-economic stability. Given its scale and expansion, the Arab revolution has left its mark as the tremendous Arab awakening characterised by numerous uprisings throughout the region. Akin to any revolution, the Arab Uprising is the result of a series of suppressed political and socioeconomic factors. 
The political systems of the Arab countries are now characterised by an interweaving of governmental structures, political parties, organisations and informal socio-political trends, which in general can be considered modern forms of the political life of the Arab world. The political regimes in the region for decades have had authoritarian and totalitarian characteristics (Boughzala \& Romdhane, 2017). Authoritarian regimes are distinguished by communist principles and/or one-party leadership. Such regimes can also be militaristic or dynastic or theocratic, some can include constitutional restrictions, forced subjugation of citizens, the excessive power of one person or party, careful control over media and judiciary, lack of free elections and similar other dictatorial ways of domination(Lesch \& Haas, 2016). Totalitarian regimes operate based on a central ideology and are led by one person or party. The media, other communication channels and public freedom are limited, the head of the state centrally controls the economy.

The violent change of political regimes and the numerous victims have come as a surprise to analysts despite the obvious prerequisites for the destabilisation of the old regimes in the region. The systemic crisis has led to violent regime changes in Tunisia, Egypt, Libya, Yemen, and the civil war in Syria. The turmoil has manifested itself in all the countries of the Arab world. Each of the countries has its own specifics, political and socio-economic prerequisites and conditions. However, all of them have undergone radical political transformations that have more or less similar features (Fraihat, 2016). The consequences of Arab revolutions are still emerging, and already some patterns can be traced that require a scientific explanation.

In the political sphere, the level of political cohesion has increased. There are also the following signs of globalisation: the appearance of transnational corporations, international banks, the expansion of the Internet community (Abdalla, 2018).

The political causes or preconditions of the Arab uprisings can be attributed to the weakened civil society, political opposition in the region and political crisis in general since the 1980s. The political roots of the Arab uprisings may be linked to the outcomes of the World Wars and the Cold War (Kurpebayeva, 2019a).

The Arab States function under authoritarian or totalitarian regimes with integrated military security and state-controlled economies (Heydemann, 2018; Steinert-Threlkeld, 2017). For example, in these countries, the totalitarian rule allows a president or king to possess an ultimate decisive power, appoint Ministers, control the legislative and judicial systems, declare war and other strategies affirming subservience to the state. Such a president/king is considered the father of the nation and the commander of the army; the rules are based on certain religious or political doctrines, revolutionary claimed principles, achievements of the coup, royal hereditary right, Sharia law and others.

Such political rule leads to poor governance or lack of governance. For example, Libya, under the rule of Gaddafi (for more than four decades) was the most repressive and corrupt political and economic regime in North Africa. There were presidents in countries such as Egypt, Yemen, Tunisia, Syria and Algeria that ruled for over 20 years. Citizens under such regimes did not have any rights and were subject to political corruption. For example, the rule of Mubarak in Egypt, Gaddafi in Libya and Ben Ali in Tunisia for decades forced some sectors of the economy, including tourism, banking and much more to function within the ruling family or its associate members through the means of special services, private security, the dominance of the ruling party, state of emergency, martial law, arbitrary arrests and trials. Thus, there was clearly an oligarchy, which gave rise to political and economic corruption.

From a political point of view, Middle East and North Africa (MENA) region states demonstrate excessive powers on the part of one person or a group of persons through concentration of power, nepotism and the absence of political pluralism (Bayat, 2017). Arab population finally opposed a monopoly power of monarchical or 
military dynasty over civil society and demanded a shift to a coherent and robust political system.

Based on the above, it can be argued that, at the present stage, the critical functions of authoritarianism are close to exhaustion and thus the realities of the industrial era give rise to a need for a new political system. To a large extent, this process is accelerated by globalisation. As a result, the majority of the population of authoritarian states, and primarily the politically active part of it, loses motivation to support the existing order and requires changes in the direction of democracy. Many countries of Latin America, South Korea, Taiwan, the Philippines, Indonesia and several other countries of Asia and Oceania have already passed through this critical stage of authoritarianism, and now the Arab world is to do the same.

In the Arab world, it is more than challenging to introduce democracy into politics and economics since there are still political elites that control the economic resources and live in luxury. Besides, the suppression of individual rights and freedoms has ultimately led to an Arab Spring phenomenon that bases on collective social action.

\section{Socio-Economic Background}

The socio-economic background of the Arab uprisings is also associated with the political regimes of the countries of the region. The economic crisis of 2008 worsened the economic situation in the MENA region. Despite the adaptation and application of several economic models as well as the recommendations and policies of the International Monetary Fund (IMF) and the World Bank (WB), several states of the region have failed to ensure a sustainable and efficient economy (Veninga \& Ihle, 2018). The high dependence on oil production and exports of most countries in the region has undoubtedly provided a surplus. However, the lack of a globalised private sector has affected employment status across the region, given the volatility in the oil market.

The global financial crisis affected most of the Arab States, having a significant impact on their economies. Moreover, the degree of its impact was directly proportional to the volume of financial and economic relations of an Arab state with the outside world. During the Arab spring, three socially significant stages could be distinguished that Arab countries encountered. The first stage was during the uprising on antiautocratic regimes. The second phase was connected to the political crisis when political parties tried to seize power and rule; however, they were secular or Islamic, and this provoked the clashes between police and protesters. The last stage was characterised by low foreign direct investment, low growth, a high budget deficit, high debt, high unemployment rates, high poverty and low living standards.

While countries that produce and export hydrocarbons have benefited greatly, countries that do not depend on this factor have significantly suffered too. The examples of Tunisia and Egypt can be cited in this regard. International financial institutions set various macroeconomic targets for countries to meet. However, they were unable to focus on the social aspects of their societies, which led to rising fuel prices with food shortages. This observation bear resonance to the observation made by Das et al. (2019). Thus, the international crisis, combined with the weakening of the domestic financial system, economic deficits, public debt, political impotence, lack of jobs, failure of development plans and oil price volatility, affected both oil-producing and nonoil-producing countries in the region.

States are characterised by inflation and rising commodity prices. Arab economies have fallen into deficit, and economic performance in most of these countries has declined by more than $5 \%$ a year. Trade markets have risen prices, while inflation rates in some rebellion countries have increased by $100 \%$ in a few years, and public debt has risen to an unprecedented record. . Help from partners and allies in stopping the deterioration of these economies has not been successful. Poverty caused by rising food prices is considered one of the main causes of chaos, civil disobedience, riots and even revolutions in many countries (Bekisheva et al., 2018). 
While unrest and riots for food are not new to the MENA region, countries such as Tunisia, Yemen, Egypt and Morocco experienced protests between 2007 and 2008, given the rapid rise in food prices. The overall effect of the global economic crisis combined with poor economic governance in the region worsened the economic situation (Abdou \& Zaazou, 2018). The general mood of the affected citizens gradually deteriorated, and a collective outbreak was visible, which might be associated with collective economic discontent among the population, unstable business cycles, volatile labour market. It can also be argued that demographic changes in the region are a significant cause of Arab uprisings. Between 1970 and 2010, the Arab world experienced massive population changes.

Unemployment rates in the region, especially in countries such as Tunisia, Egypt and Morocco, are as well the causes of Arab uprisings. Lower production rates in the region have led to higher unemployment rates, and youth unemployment has ultimately led to discontent among young people. The official unemployment rate was stable between 1991 and 2010. During economic reforms, the unemployment rate fell due to a sharp drop in the birth rate. The main demographic difficulty was the unemployment rate of 1 million people in 2011, including young people. They decided that the regime must be overthrown for a better new life (Hänska Ahy, 2016). Ultimately, political instability and nepotism drove the young workforce to revolt against growing poverty and widespread inequality in societies.

Live reports of protests in Egypt and Tunisia and excessive use of social media platforms such as Facebook and Twitter have influenced the population to act against the oppressive forces and injustice (Farhan \& Varghese, 2018). Since social networks help individuals and groups exchange information online, as well as generate and disseminate thematic content, it can be argued that in terms of social context the most powerful feature of the Arab uprisings is the use of information technology as an essential tool for transmitting information, mobilising citizens, and managing protest groups. However, in the macro-social assessment, it is necessary to consider the three most important reasons for revolts. These reasons are as follows: the socialpsychological state of society, the global economic crisis and foreign influence.

\section{Discussion}

The Arab spring in the Middle East has illustrated how difficult it is to forecast political events in this region (Stopczyński, 2018). The political consequences of the Arab Spring uprisings can be narrowed down to the emergence of religious, political parties with radical agendas, followed by an increase in the activity of political radicalism along with the iron fist of the rule of the Caliphate. The Arab Revolution, in addition to protests and political changes in most countries of the region, influenced the political order in the Arab world, impacting national systems (Kurpebayeva, 2019b).

It is important to consider that Islam is a social component of political development in the Arab countries. The growth of religious spirit and the deepening of the Islamisation of society negatively affect the democratic processes in the region (Hudson-Flege, 2019). The Islamic world was separated from the global decision-making centre in the second half of the 20th century. However, now, Islam can be considered one of the most critical factors in geopolitical processes of the world community.

The social consequences of the Arab uprisings can be summarised as the loss of public freedom, the violation of the rights of women and minorities, and the death of hope for democracy. The loss of public freedom implies the impossibility of the media to illustrate the public's opinion. Besides, Islamic parties and factions force their citizens to adhere to their Islamic rules and traditions, preventing people from enjoying religious freedom. Human rights, human personality and dignity are widely impeded. Continuous unrest in any society can lead to severe changes in the political, economic and social structure of the state. It also becomes difficult to implement regional development strategies as they cannot be predicted over time (their relevance, even in the short term, is difficult to assess) (Tronin et al., 2019). The said 
leads to the fact that the countries of the region will continue to be in a state of stagnation, while maintaining low attractiveness for external investors.

The failure of economic models and the global recession has led to new levels of fundamental problems, such as increased unemployment, political corruption and the wide gap between rich and poor. Consequently, society is deprived of its basic structure. These aspects have further widened the gap between the state and citizens.

Thus, the macroeconomic risk level of the affected states increases, preventing tourism, the influx and outflow of foreign direct investments, creating an interfaith split in civil society, and, thereby, laying the seeds for civil wars. The uprisings of the Arab spring, unfortunately, boiled down to simple civil wars throughout the region, and this chaos claimed the lives of thousands of civilians. Violence is used by the parties involved as a weapon, which spreads across geographic boundaries (Kurpebayeva, 2018). Globalisation seeks to create a geopolitical balance through the regionalisation of international relations. However, the modern global world is not limited to a certain geographical space, and is multidimensional, which critically complicates the process of "balancing".

\section{Conclusion}

The Arab spring as a phenomenon can be considered not only as a political process but also as a social shock for the entire Islamic population, setting a precedent for the cultural transformation of Islam into a full-fledged political influence factor. After the revolutions, the MENA region has lost the stability of economic development and attractiveness to external investors and international institutions, it is also not possible to diversify macroeconomic risks in the region in the short and medium-term. Changing political regimes requires conceptually new agreements at the international level since the global energy market remains hugely dependent on stability in the countries of the Arab world.
Results show that the cross-border nature of the changes provoked by the Arab spring causes an indirect influence on the transformation of the humanitarian sphere even in societies not affected by the revolution directly. Information globalisation opens up opportunities for the previously closed societies to protect their rights and allows the dissemination of information through interactive platforms, which in general can be regarded as a step towards the democratisation of Islamic states.

MENA remains a region in need of restructuring of macroeconomic activity; however, the models proposed by international institutions do not work or are not effective for existing conditions in this market. The new leaders of the Arab countries are in a challenging situation. On the one hand, they must achieve economic security for the state, which requires unpopular decisions. On the other hand, the policy should be built taking into account the moods and demands of the masses, because if the expectations of the population are not met, a new wave of revolutions will cover the country (as the region's experience shows).

The practical relevance of the study is that the obtained results allow one to understand the role and place of the Islamic uprisings and assess the prospects for the MENA countries.

\section{References}

Abdalla, N. (2018). Youth movements in the Egyptian transformation: strategies and repertoires of political participation. Dynamics of Transformation, Elite Change and New Social Mobilization (pp. 44-63). Routledge, London, UK. doi:63.10.1080/13629395.2015.1081445

Abdou, D. S., \& Zaazou, Z. (2018). Arab Spring future challenges: evidence from Egypt. Review of Economics and Political Science. doi: 10.1108/REPS-07-2018-004

Al-Shammari, N., \& Willoughby, J. (2019).

Determinants of political instability across Arab Spring countries. Mediterranean Politics, 24(2), 196-217. doi: 10.1080/13629395.2017.1389349 
Bayat, A. (2017). Revolution without revolutionaries: Making sense of the Arab Spring. Stanford University Press, Redwood, USA.

Bekisheva, S., Begaliyev, Y., Baisagatova, D., \& Imangaliyev, N. (2018). Social and Economic Aspects of Extremism and Terrorism and Reasons for Their Emergence. Space and Culture, India, 6(4), 66-74. doi:

10.20896/saci.v6i4.382

Boughzala, M., \& Romdhane, S. B. (2017). Transition from Autocracy to Democracy in Tunisia, Factors Underlying the Tunisian Uprising and the Prospects for Consolidating the Transition to Democracy. Democratic Transitions in the Arab World. Cambridge University Press, Cambridge, UK.

Das, D., Talukdar, M. K., \& Mahanta, R. (2019). Energy: An Exploratory Study on the Experience of Developing Countries in the Context of Development and the State of the Environment. Space and Culture, India, 7(1), 27-38. doi:10.20896/saci.v7i1.235

Farhan, A. A. N., \& Varghese, P. (2018). Facebook Utilization and Arab Spring Movement: A Study among Yemeni Youth. International Journal of Social Sciences and Management, 5(1), 5-9. doi: 10.3126/ijssm.v5i1.18971

Fraihat, I. (2016). Unfinished revolutions: Yemen, Libya, and Tunisia after the Arab spring. Yale University Press, London, UK.

Hänska Ahy, M. (2016). Networked communication and the Arab Spring: Linking broadcast and social media. New Media \& Society, 18(1), 99-116. doi:

$10.1177 / 1461444814538634$

Heydemann, S. (2018). Explaining the Arab uprisings: Transformations in comparative perspective. Dynamics of Transformation, Elite Change and New Social Mobilization (pp. 192204). Routledge. Publisherdoi: 10.1080/13629395.2015.1081450

Hudson-Flege, M. D. (2019). Respect for Human Rights as a Predictor of Arab Spring Intensity: A Replication and Extension Study. International
Journal of Political Activism and Engagement (IJPAE), 6(2), 1-13. doi: 10.4018/IJPAE.2019040101

Koehler, K. (2017). Political militaries in popular uprisings: A comparative perspective on the Arab Spring. International Political Science Review, 38(3), 363-377. doi:

$10.1177 / 0192512116639746$

Kurpebayeva, G. (2018). The geopolitical influence of the Arab spring on the Middle East. Bulletin of Kazakh National Pedagogical University after Abai. Series of Sociological and Political Sciences, 4(64), 121-126.

Kurpebayeva, G. (2019a). Comparative analysis of the prerequisites of the political processes of the "Arab Spring". Journal of Oriental Studies, 90(3), 45-55.

Kurpebayeva, G. (2019b). Problems of transformation of political systems in the Arab world. The Strategies of Modern Science Development (pp. 95-100), Scientific Publishing Center "Discovery", Morrisville, USA.

Lesch, D., \& Haas, M. L. (2016). The Arab spring: The hope and reality of the uprisings. Westview Press. doi: 10.4324/9780429494581

Shayakhmetov, O. M., Imasheva, G. Y., Almukhametov, A. R., Mukhitdinov, R. S., \& Paltore, Y. (2018). Systematising the Microstructure of a Modern Dictionary of the Arabic Language. Space and Culture, India, 6(2), 34-45. doi: 10.20896/saci.v6i2.340

Spierings, N. (2019). Democratic disillusionment? Desire for democracy after the Arab uprisings. International Political Science Review, doi: 10.1177/0192512119867011

Steinert-Threlkeld, Z. C. (2017). Spontaneous collective action: Peripheral mobilization during the Arab Spring. American Political Science Review, 111(2), 379-403. doi: $10.1017 /$ S0003055416000769

Stopczyński, A. (2018). The Arab SpringImplications for the Russian Federation. International Studies. Interdisciplinary Political and Cultural Journal, 21(1), 127-140. doi: 10.18778/1641-4233.21.09 
Tronin, S., Rodermel, T. A., Uspaeva, M. G., Shashkova, A. V., \& Calesci, M. (2019).

Formation of Innovative Strategies of Regional Economic Development. Space and Culture, India, 7(2), 65-75. doi: 10.20896/saci.v7i2.457

Tsapko, M. I., Valyarovskiy, F. I., Maiboroda, E. T., Khusainova, E. N., \& Varnavskaya, O. O.

(2018). Language identity as a unifying identity: Linguistic, ethnopolitical and international legal aspects. Space and Culture, India, 6(2), 121-129. doi: $10.20896 /$ saci.v6i2.360
Veninga, W., \& Ihle, R. (2018). Import vulnerability in the Middle East: effects of the Arab spring on Egyptian wheat trade. Food security, 10(1), 183-194. doi: 10.1007/s12571017-0755-2

Vida, I. S., \& Cenit, M. D. (2017).

Autocratisation, Authoritarian Progressions and Fragmented States. In Political change in the Middle East and North Africa (pp. 403-426).

Edinburgh University. doi: 10.3366/edinburgh/9781474415286.003.0018 